\title{
Comparative Analysis of the Factors Affecting the Economic Growth in Georgia and Assessment of the Efficiency of the Budget Policy
}

\author{
Givi Makalatia, PhD Student \\ Ivane Javakhishvili Tbilisi State University, Georgia
}

\begin{abstract}
Correlation among the macroeconomic indicators of Georgia was considered in this article. Also, the predictors of the growth of Gross Domestic Product were revealed. Aim: This paper focuses on defining the role of the state budget among the factors having a significant impact on the increase of the Gross Domestic Product and assessment of the efficiency of the budget policy. Methods: 16 factors affecting the increase of the Gross Domestic Product was studied. Correlations among the factors were defined by means of the Pearson Correlation Analysis. The forecasting factors were assessed by means of the multiple linear regression analysis. In order to verify the degree of the impact of the factors, the regression analysis was carried out in other equal conditions. Results: Linear relation was presented between the state budget and the Gross Domestic Product. Increase in the Gross Domestic Product of Georgia would be defined mostly with the tax revenues into the state budget and afterwards, the direct foreign investments. The state budget, compared with the goods export, facilitates an increase of the service export even more. Conclusions: The main factor affecting economic growth is the tax revenues payable to the state budget. On basis of the regression analysis, it has been revealed that the state budget facilitates an increase of the export of the service even more, compared with the goods export. This preconditions the fact that, in the conditions of the harsh negative foreign trading of Georgia, the efficiency of the budget policy is not high. Chosen priorities, therefore, need to be reviewed. Nowadays priorities include social insurance, social infrastructure, and education.
\end{abstract}

Keywords: State budget, budget policy, goods export, service export

\section{Introduction}

Many economic as well as non-economic factors affect Gross Domestic Product (Afghan, 1998). Thus, the main challenge is verification of 
the predictors of economic growth. In the conditions of the modern paces of globalization and harsh competition at the international markets, it might be hard to imagine that developing country could achieve high level of economic growth and, therefore, competitiveness of the national market without the effective budget policy. Compared with the classic doctrines, Keynesian Theory defines that the state procurements in particular have a significant impact on the stimulation of the manufacturing, which is finally reflected on the increase of the aggregate demand. "Effective Demand" proposed by Keynes (1936) is a kind of insurance for the market in order not to fall into the crisis. Research by Auerbach confirms that the effect of the fiscal multiplicator during the recessive period is much higher compared to the recovery period (Auerbach et al., 2012). Due to the outcomes of the research by Chude, increase of the state expenditures in the starting period of the recessive processes stimulates the aggregate demand, which gradually secures the maintenance of the trend for the gradual increase of the economy (Chude et al., 2013). The research carried out by Çakerrion based on the example of Albania confirms that the state expenditures are considered as the strong instrument for economic growth, especially in developing countries. Besides, it was indicated that the state interventions implemented in the post-global financial-economic crisis period of 2008 became more actual again (Çakerri et al., 2014).

\section{Goal of the Research}

The goal of this research is to highlight the factors acting on the Gross Domestic Product of the role of the state budget and on the assessment of the efficiency of the budget policy.

\section{Methods}

The study uses data of the National Statistics Office of Georgia and the Ministry of Finances. In this article, the following factors have a significant effect on the increase of Gross Domestic Product: the state budget, the state debt, the total foreign debt, the tax revenues in the state budget, the value added tax, the foreign grants, the number of the employees, increase of the population, the direct foreign investments, the credits of the commercial banks, the deposits, the money remittances, the goods export, the service export, tourism, and transportation. Statistical analysis covers the data of 2003-2018. For assessment of the efficiency of the budget policy of Georgia, along with the economic growth, the interrelations among the state budget, the goods export, and the service export were considered. Correlations among the factors were defined by means of the Pearson Correlation Analysis, and the forecasting factors were assessed by means of the multiple linear regression analysis (Poo, 2014). In order to verify the degree of the impact of the factors, 
regression analysis was carried out in other equal conditions. Computer program SPSS version 23 was used for statistical analysis. GEL refers the national currency of Georgia.

\section{Results}

Based on the result of the statistical analysis, we have depicted the correlations among them in order to assess the purpose of inclusion of the selected factors in this research. The correlation is reliable if $p<0.05$. The statistical analysis covers data from the year 2003-2018.

Consequently, the following shows a reliable positive correlation with the Gross Domestic Product: the state budget - r=0.982*, $\mathrm{p}<0.001$; the state debt $-\mathrm{r}=0.919 * *, \mathrm{p}<0.001$; total foreign debt $-\mathrm{r}=0.950 * *, \mathrm{p}<0.001$; direct foreign investments $-\mathrm{r}=0.826^{*}, \mathrm{p}<0.001$; tax revenues into the state budget $\mathrm{r}=0.992 * *, \mathrm{p}<0.001$; value added tax $-\mathrm{r}=0.989 * *, \mathrm{p}<0.001$; credits of the commercial banks $-\mathrm{r}=0.945^{*}, \mathrm{p}<0.001$; deposits $-\mathrm{r}=0.945^{*}, \mathrm{p}<0.001$; money remittances of the labor emigrants - $\mathrm{r}=0.984^{* *}, \mathrm{p}<0.001$; service export $\mathrm{r}=0.930 * *, \mathrm{p}<0.001$; tourism $-\mathrm{r}=0.902 * *, \mathrm{p}<0.001$; transportation $-\mathrm{r}=0.974 *$, $\mathrm{p}<0.001$; goods export $-\mathrm{r}=0.956^{* *}, \mathrm{p}<0.001$. Thus, based on the result of the statistical analysis, it was revealed that the increase of the population definitely does not correlate with any other factor.

The following shows the reliable positive correlation with the state budget: the state debt $-\mathrm{r}=0.927 *, \mathrm{p}<0.001$; total foreign debt $-\mathrm{r}=0.954 * *$, $\mathrm{p}<0.001$; direct foreign investments $-\mathrm{r}=0.776^{* *}, \mathrm{p}<0.001$; tax revenues into the state budget $-\mathrm{r}=0.994 * *, \mathrm{p}<0.001$; value added tax $-\mathrm{r}=0.982^{* *}, \mathrm{p}<0.001$; credits of the commercial banks $-\mathrm{r}=0.938^{* *}, \mathrm{p}<0.001$; deposits $-\mathrm{r}=0.936^{* *}$, $\mathrm{p}<0.001$; money remittances of the labor emigrants $-\mathrm{r}=0.978^{* *}-\mathrm{p}<0.001$; service export - $\mathrm{r}=0.920 * *, \mathrm{p}<0.001$; tourism - $\mathrm{r}=0.890 * *, \mathrm{p}<0.001$; transportation $-\mathrm{r}=0.968 * *, \mathrm{p}<0.001$; goods export $-\mathrm{r}=0.940 * *, \mathrm{p}<0.001$.

All the factors are reliably correlated with one another, except for the number of the employees and increase of the population, which do not correlate with any factor. Based on the result of the statistical analysis, it was revealed that the lowest correlation indicator is a characteristic for the grants, and the other factors are relatively high.

Quantitative indicators are considered as reliable if the Student coefficient is $\mathrm{T}>1.96$ and $\mathrm{p}<0.05$. The correlation reflects the degree of the relationship, and the regression is the relation form expressing equation. By solving the system of the equations, we obtain X0 and X1(tax revenues into the state budget), X2 (State Budget), X3 (Foreign Direct Investments), etc. Therefore, this is the number of the factors, which we have already indicated. $\mathrm{X} 0$ is the starting value and the remaining parameters show how the change of the independent variables with one unit would change the causing function. 
Table 1. Dependent Variable: Gross Domestic Product

\begin{tabular}{|c|c|c|c|c|c|c|c|}
\hline & \multicolumn{2}{|c|}{$\begin{array}{l}\text { Unstandardized } \\
\text { Coefficients }\end{array}$} & $\begin{array}{c}\text { Standardized } \\
\text { Coefficients }\end{array}$ & \multirow[t]{2}{*}{$\mathbf{t}$} & \multirow[t]{2}{*}{ p } & \multirow{2}{*}{\multicolumn{2}{|c|}{$\begin{array}{l}\text { 95.0\% Confidence } \\
\text { Interval for B }\end{array}$}} \\
\hline & B & St. Error & Beta & & & & \\
\hline (Constant) & 13105.25 & 321.49 & & 40.76 & 0.001 & 12410.71 & 13799.80 \\
\hline $\begin{array}{l}\text { The tax } \\
\text { revenues into } \\
\text { the state } \\
\text { Budget } \\
\text { (million GEL) }\end{array}$ & 1.55 & 0.09 & 0.909 & 17.79 & 0.001 & 1.36 & 1.74 \\
\hline
\end{tabular}

Based on the result of the regression analysis, the following equation was obtained. Here, the primary factor is the tax revenues into the state budget given as GDP $=13105,3+1.552 * \mathrm{X} 1$ (Tax revenues based on the state budget).

The regression analysis showed that the Gross Domestic Product is defined mostly with the tax revenues in the state budget and then with direct foreign investments.

Due to the fact that the subject of this research is observance of the relation between the state budget and the Gross Domestic Product, it is interesting to ascertain the outcome the regression analysis brings when other factors are exempted.

Table 2. Forecasted Factor: Gross Domestic Product

\begin{tabular}{|c|c|c|c|c|c|c|c|}
\hline & \multicolumn{3}{|c|}{$\begin{array}{l}\text { Unstandardized } \\
\text { Coefficients }\end{array}$} & \multirow{2}{*}{$\begin{array}{c}\begin{array}{c}\text { Standardized } \\
\text { Coefficients }\end{array} \\
\text { Beta }\end{array}$} & \multirow[t]{2}{*}{$\mathbf{t}$} & \multirow[t]{2}{*}{$\mathbf{P}$} \\
\hline & & B & Std. & Error & & & \\
\hline \multicolumn{2}{|c|}{$\begin{array}{l}\text { State Budget (Million } \\
\text { GEL) }\end{array}$} & 1.38 & & 0.071 & 0.98 & 19.49 & $<0.001$ \\
\hline \multicolumn{2}{|c|}{ (Constant) } & 12496.81 & & 536.40 & & 23.30 & $<0.001$ \\
\hline \multicolumn{8}{|c|}{ ANOVA } \\
\hline & \multicolumn{2}{|c|}{ Sum of Squares } & df & \multicolumn{2}{|c|}{ Mean Square } & $\mathbf{F}$ & $\mathbf{P}$ \\
\hline Regression & & 344280432.93 & 1 & \multicolumn{2}{|c|}{344280432.93} & 380.01 & $<0.001$ \\
\hline Residual & & 12683769.51 & 14 & \multicolumn{2}{|c|}{905983.54} & & \\
\hline Total & & 6964202.44 & 15 & & & & \\
\hline
\end{tabular}

The precise test of Fisher shows that the outcomes are reliable, i.e., $-\mathrm{p}<0.05$. The regression of the relation of the Gross Domestic Product with the state budget is expressed as: GDP $=12496.813+1,378 * \mathrm{X} 1$ (State Budget).

Below is a graphical illustration of the relationship between the state budget of Georgia and the Gross Domestic Product. 


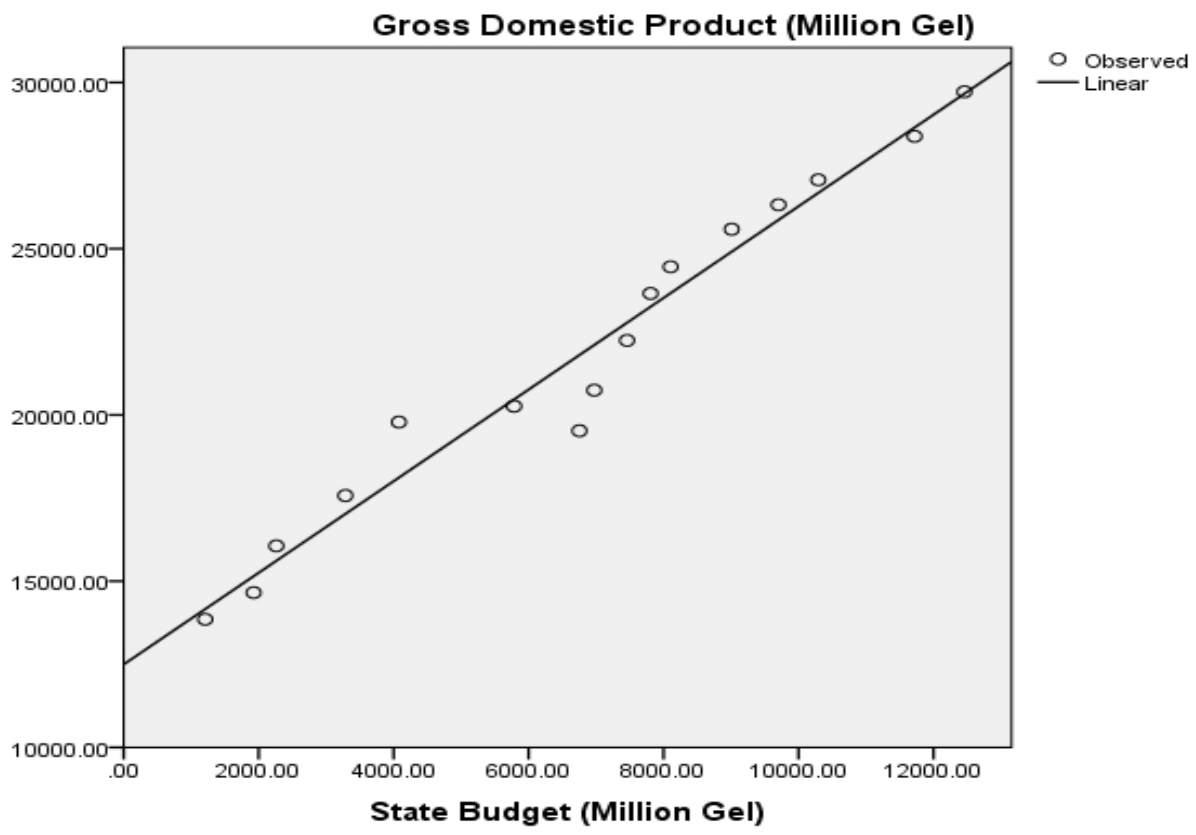

Figure 1. Relation between the state budget of Georgia and the Gross Domestic Product

One of the main defining factors of the effective budget policy is the increase of the goods export compared with the import (Mushtaq et al., 2014). Therefore, it is necessary to consider the kind of relation between the state budget and the goods export.

Table 3. Forecasted Factor - goods export

\begin{tabular}{|c|c|c|c|c|c|c|c|c|}
\hline & \multirow{2}{*}{\multicolumn{3}{|c|}{$\begin{array}{c}\text { Unstandardized } \\
\text { Coefficients }\end{array}$}} & \multirow{3}{*}{\multicolumn{2}{|c|}{$\begin{array}{c}\begin{array}{c}\text { Standardized } \\
\text { Coefficients }\end{array} \\
\text { Beta }\end{array}$}} & \multirow{3}{*}{$\mathrm{T}$} & \multirow{3}{*}{$\mathrm{P}$} \\
\hline & & & & & & & & \\
\hline & & B & \multicolumn{2}{|c|}{ Std. Error } & & & & \\
\hline \multicolumn{2}{|c|}{$\begin{array}{l}\text { State Budget (Million } \\
\text { GEL) }\end{array}$} & 0.629 & \multicolumn{2}{|c|}{0.061} & 0.940 & & 10.312 & 0.000 \\
\hline \multicolumn{2}{|c|}{ (Constant) } & -553.106 & \multicolumn{2}{|c|}{462.565} & & & -1.196 & 0.252 \\
\hline \multicolumn{9}{|c|}{ ANOVA } \\
\hline & \multicolumn{2}{|c|}{ Sum of Squares } & Df & \multicolumn{2}{|c|}{ Mean Square } & & $\mathbf{F}$ & Sig. \\
\hline Regression & \multicolumn{2}{|c|}{71640982.671} & 1 & \multicolumn{2}{|c|}{71640982.671} & & 106.335 & 0.000 \\
\hline Residual & \multicolumn{2}{|c|}{9432163.660} & 14 & & & & \\
\hline Total & \multicolumn{2}{|c|}{81073146.331} & 15 & \multicolumn{2}{|c|}{673725.976} & & & \\
\hline
\end{tabular}

The precise test of Fischer shows that the outcomes are reliable, i.e., $\mathrm{p}<0.05$. 


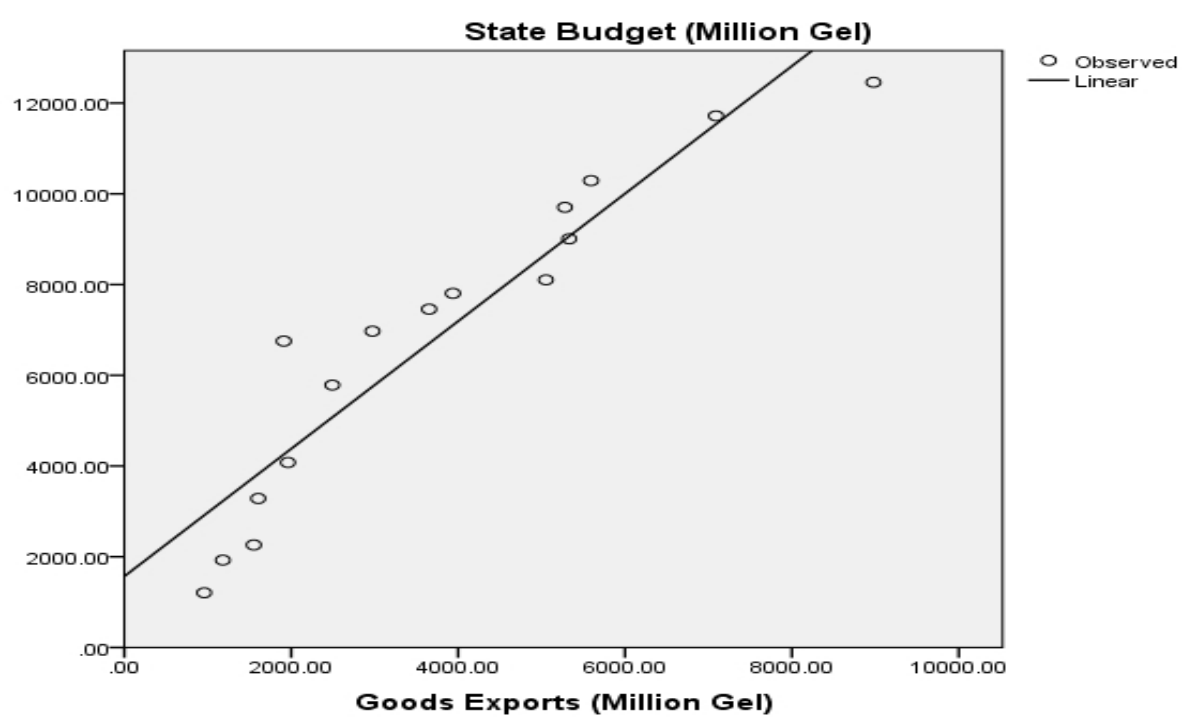

Figure 2. Relation between the state budget of Georgia and the goods export

The goods export depends on the state budget, although the relation is not linear. Since the service export has been increased significantly compared with the goods export in Georgia, by means of the statistical analysis, we can observe the relation between the state budget and the service export.

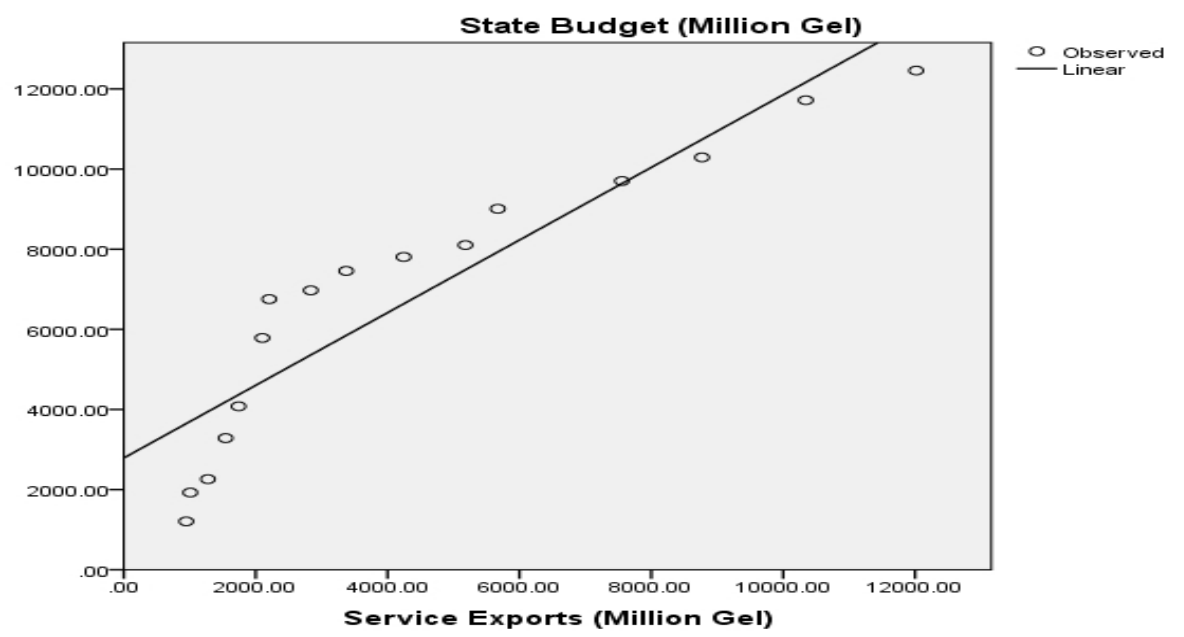

Figure 3. Relation between the state budget of Georgia and the service export

The precise test of Fischer shows that the outcomes are reliable i.e., - $\mathrm{p}<0.05$. From the graph above, the relation is more or less linear.

For assessment of the efficiency of the budget policy of Georgia, it is necessary, along with the economic growth, to consider the goods export growth compared with the import. According to the attitude obtained based on 
the result of the regression analysis, the state budget facilitates an increase of the service export even more when compared with the goods export. On basis of the factual statistical data, if the curves constructed are observed, the indicated difference is obvious.

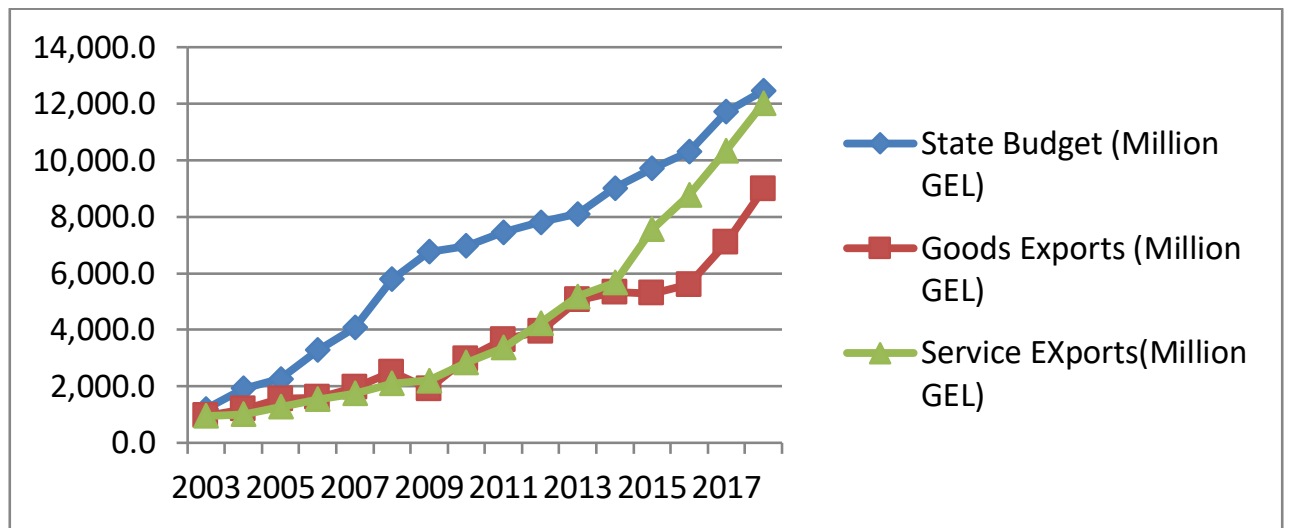

Figure 4. The interrelation by and between the state budget and the export (in Million GEL)

The curves are constructed by the author according to the data of the National Statistics Office of Georgia and the Ministry of Finances. Starting from 2011, the expenditures for facilitating tourism from the state budget have been increasing. Thus, this has affected positively the service export. The other large sector after tourism is transportation.

\section{Discussion}

Regression analysis showed that the Gross Domestic Product is defined mostly based on the tax revenues of the state budget and with the direct foreign investments. Therefore, we might conclude that perfection of the budget-tax system is the main task. The attitude revealed as the result of the quantitative analysis indicates that the subsequent spending of the tax revenues, which is the main constituent part of the budget policy, strongly affects economic growth. The regression analysis does not refer to the state budget itself, but the significance of the tax revenues relative to budget. Hence, it is the general revenue of the state budget and not the total expenditures. Similar research was carried out by Tabaghua which shows that based on the result of the statistical analysis of Georgia and the EU countries, part of the budget expenditures of the current year in the countries with deficit budget was carried out for funding the liabilities undertaken in the past. This currently causes decrease based on the significance of the expenditures for the sake of economic growth. The budget tax revenues, just on the contrary, positively affect economic growth. Thus, it shows which revenues are received by the state according to the activities implemented in the past. In case of profit or balanced budgets of developed countries, the analysis of the total expenditures 
of the budget is significant (Tabagua, 2016). For developing countries, permanent budget deficit has a very negative impact on economic growth over the long run (Kurantin, 2017). Due to the fact that Georgia is a developing country and is characterized with deficit budget, the revenues received from taxes play a significant role in regard to economic growth. It was indicated that the revenues received from the taxes based on the total incomes of the budget of Georgia make up $75 \%$. Of course, on the other hand, the indicated revenues are the same expenditure. Although according to the regression analysis, it shall be distinguished from the incomes of other type such as the outcome of the state interventions implemented in the past. Empirical evidence of various developing countries include the econometric analysis implemented by Nguyen in Vietnam (Nguyen, 2019), Olajidein in Nigeria (Olajide et al., 2012), and Al-Fawwaz in Jordan (Al-Fawwaz, 2016). Therefore, this confirms the positive relation between the state interventions and economic growth. As for the approaches of the budget policy, they differ according to various countries (Muinelo-Gallo et al., 2011). For example, on one hand, the budget policy of South Korea and Taiwan considered the direct intervention of the state. This is for the sake of economic growth (especially for the increase of the goods export) compared with creation of the relevant business environment compliant with the direct foreign investments, resulting to the development of the indicated countries (Kim et al., 2017). On the other hand, Ireland is quite interesting. Here, the main priorities of the budget policy were generally the introduction of the low taxes and arrangement of the infrastructure for attraction of the direct foreign investments (Bradley, 1999). The budget policy implemented by the indicated countries secured economic growth through various ways. It is important to note that mechanic "importing" of the budget policy process from the developed countries into the developing country is not purposed. However, it might be stated that for developing countries, fiscally sustainable budget is associated with the high economic growth, in short term as well as long term (Gupta et al., 2005). The impact of the state budget in economic growth would be assessed according to the implemented budget policy. Elaboration on the correct budget policy might shorten the time of economic development. Nevertheless, incorrect budget policy, along with the wasting of time, might cause degradation of the economy.

Compared with the service export, the revenues received from the goods export are rather scarce. In the last few years, the harsh negative foreign trade balance has been in Georgia. For the entire foreign trade volume, $27 \%$ comes to the export while $73 \%$ is held by the import. According to the research held by Cárdenas-García on 144 countries, the impact of the tourism to the increase in the economy is more obvious in developed countries. Here, the local manufacturing is developed. Also, in regard to the developing countries, 
the indicated attitude is weak (Cárdenas-García et al., 2015). Therefore, it is preferred that the budget policy of Georgia should facilitate an increase of the goods export.

\section{Conclusion}

In conclusion, the main independent factor affecting the economic growth stands with the tax revenues payable to the state budget. Using regression analysis, it has been revealed that the state budget facilitates increase in the export of the service even more, compared to the goods export. Hence, this preconditions the fact that in the conditions of the harsh negative foreign trading of Georgia, the efficiency of the budget policy is not high. Therefore, chosen priorities need to be reviewed. Nowadays priorities include social insurance, infrastructure, and education.

\section{References:}

1. Afghan, M. S. (1998). Economic and Non-Economic Factors in Economic Development: The Concepts and Their Differences, (Doctoral dissertation, Thesis Title (PhD), 1-23.

2. Al-Fawwaz, T.M. (2016). The impact of government expenditures on economic growth in Jordan (1980-2013). International Business Research, 9(1), 99.

3. Auerbach, A.J. \& Gorodnichenko, Y. (2012). Measuring the output responses to fiscal policy. American Economic Journal: Economic Policy, 4(2), 1-27.

4. Bradley, J. (1999). The History of Economic Development in Ireland, North and South, proceedings of the British Academy, 35-68.

5. Çakerri, L., Petanaj, M., \& Muharremi, O. (2014). The effect of government expenditures on economic growth. The case of Albania. European Journal of Social Science Education and Research, 1(2), 242-253.

6. Cárdenas-García, P.J., Sánchez-Rivero, M., \& Pulido-Fernández, J. I. (2015). Does tourism growth influence economic development?. Journal of Travel Research, 54(2), 206-221.

7. Chude, N. P. \& Chude, D. I. (2013). Impact of government expenditure on economic growth in Nigeria. International journal of business and management review, 1(4), 64-71.

8. Gupta, S., Clements, B., Baldacci, E., \& Mulas-Granados, C. (2005). Fiscal policy, expenditure composition, and growth in low-income countries. Journal of International Money and Finance, 24(3), 441463. 
9. Kim, H. \& Heo, U. (2017). Comparative analysis of economic development in South Korea and Taiwan: Lessons for other developing countries. Asian Perspective, 41(1), 17-41.

10. Kurantin, N. (2017). The Effects of Budget Deficit on Economic Growth and Development: The Experience of Ghana (1994 - 2014), European Scientific Journal 13(4), 211-224.

11. Muinelo Gallo, L. \& Roca Sagalés, O. (2011). Economic growth and inequality: the role of fiscal policies. Australian Economic Papers, 50(2-3), 74-97.

12. Mushtaq, M., Nazir, R., Bashir, I., Ahmed, S., \& Nadeem, M. (2014). Panel cointegration analysis of government spending, exports, imports and economic growth. International Review of Research in Emerging Markets and the Global Economy, 1(2), 81-89.

13. Nguyen, H.H. (2019). The Role of State Budget Expenditure on Economic Growth: Empirical Study in Vietnam. The Journal of Asian Finance, Economics and Business (JAFEB), 6(3), 81-89.

14. Olajide, O., Akinlabi, B., \& Tijani, A. (2012). Agriculture resource and economic growth in Nigeria. European Scientific Journal, 8(22), 103115.

15. Poo Rodriguez, M. J. (Ed.). (2014). Computer-aided introduction to econometrics. Springer Science \& Business Media, 350

16. Tabaghua, S. (2016). The Influence of Government Size on Economic Growth, Economics and Business, 9(1), 45-61. 